\section{CROSS-SECTIONAL ANALYSIS OF FACTORS AFFECTING OUT-OF-POCKET HEALTHCARE EXPENSES IN SERBIA}

\section{INTRODUCTION AND LITERATURE REVIEW}

Previous research has shown a significant interdependence of economic determinants in the context of impacts on out-of-pocket expenses in healthcare. These costs are defined as each individual's health care costs that are not collected through insurance (directly or through reimbursement) (1). This type of cost includes deductibles, coinsurance, and copayments for covered services, plus all costs for services that aren't covered (1). At the Republic of Serbia, World Bank research indicates too high out-of-pocket expenditures for healthcare, which in 2018 were at the level of 38 percentage points of total health expenditure. The world rate of out-of-pocket expenses for healthcare (calculated as \% of current health expenditure) is at the level of 18 percentage points (2). If we look at the index of out-of-pocket expenses in healthcare per capita, in Serbia, it is at a level of 236 US dollars for 2018 (2). The global analysis shows that the minimum of the out-of-pocket expenses per capita are in Kiribati (i.e., 0.19), while the highest is in North America with 1106 USD (2). It is considered a value of 103.99 as an average for middle-income countries, while in Serbia, it is more than double this amount. This is a very worrying amount of costs that are outside the regular costs related to the financing of the health system through contributions to the salaries of employees and employers. Let us remind that the health insurance contributions of each employee are at the level of $5.15 \%$ as well as for the employer, while in the case of unemployment contributions, it is additionally taxed at $0.75 \%$ (at the expense of both the employee and the employer) (3).

\section{SUMMARY}

Key words: demographic factors, health factors, out-of-pocket expenses, socio-economic factors

Out-of-pocket expenses in healthcare show the level of direct payments by individuals paying for the healthcare services that are not covered by the insurance. In the Republic of Serbia, high level of out-of-pocket expenses is present considering dominant Bismarck model of healthcare system and level of user income. Previous research shows the significant impact of the socio-economic and healthcare system indicators affecting out-of-pocket expenses. The objective is to perform a cross-sectional analysis of the economic, healthcare, and demographic variables impact on the out-of-pocket expenses. We use quantitative methods of analysis of data collected for the data time frame from 2000 2018. Results show a high impact of the 7 out of 13 factors we explored.

Milorad Stamenović, Research Fellow, Inventis CTC, Francois Grosso 7, Nice, Republic of France, e-mail: milorad.stamenovic@ skema.edu 
In the case of Bismarck's model of the health care system in force in the Republic of Serbia, it is considered that it is solidarity and universal health insurance that covers almost the entire population. However, it has been shown that the costs outside the paid insurance that should cover nearly the complete services of the health system are much higher than the price paid through the health contributions. Also, what is indicative is that if the amount of out-of-pocket health care costs exceeds $50 \%$ of total health care costs, it can be considered whether the Republic of Serbia has a dominant public or private health care sector. Keeping in mind the socio-economic characteristics of the population, it seems that these costs are extremely high for the citizens. Therefore, it is important that there is an understanding of the impact of important factors on outof-pocket costs in order to further regulate but also optimize the health, economic and demographic system to correct such high expenditures for citizens in the process of providing health care. This paper follows global trends in the analysis of out-of-pocket costs and impact factors. Namely, Shaikh and Singh prepared a paper showing the factors influencing out-of-pocket expenses in the form of per capita health expenditure, household final consumption expenditure, and public health expenditure (4). Okello and Njeru presented the influences of the following factors affecting out-of-pocket expenses: Household Monthly Income, Duration of Occupation, and Household Cost of Medical Services (5). Ebaidalla and Ali investigated the risk of catastrophic health expenditure using factors influencing household's income, the incidence of disease, education, household size, number of household's members over 65 years and below 5 years old - showing that these factors are of great importance for height and risk of increase out-of-pocket expenses (6). Mahmud et al. have addressed the issue of burdening households with out-of-pocket costs for health services, which poses one of the greatest threats to household sustainability in financial terms (7). These researchers used the following factors influencing the amount of out-of-pocket health care costs: socio-economic data at the household level, including family earnings, consumption, and expenditures, assets, housing conditions, as well as individual-level data on demographic variables (age, sex, and marital status), education, employment, health, disability, and other information (7). Also, Petrera and Sanchez determined determinants of out-of-pocket spending among the poor population. They used influencing factors: affiliation with the Comprehensive Health Insurance, level of family expenditure per capita, age group 0-5 years, being a woman of childbearing age ( $15-49$ years), being an older adult (over age 60 years), family burden (using the number of members of the household as a proxy indicator), and the level of complexity of the service provider (8). 
The characteristics of these studies indicate the need to analyze out-of-pocket expenses in healthcare from different angles. Namely, on the one hand, there is the problem of sustainability and stability of the health system, then healthcare access, and also of great importance are the impacts on the financial sustainability of households on which factors out-of-pocket expenses has a significant effect. This paper has tried to categorize the factors influencing out-of-pocket expenses through economic, demographic, and health indicators. Follo-

Out of pocket expenses are influence by economic, demographic and health indicators wing this, we created independent variables for further regression analysis, through which we tried to show the factors of importance on out-of-pocket expenses in these areas.

Also, we should keep in mind other problems in the sustainability and development of the health system of the Republic of Serbia, as well as other important factors such as innovation in the biomedical and pharmaceutical industry, cooperation with international organizations, and political factors of stability and stability and independence of institutions, etc. (9, 159183); (10); (11). Those factors might have a significant impact on the level of observed costs and should be the topic of future - more complex analysis.

\section{METHODOLOGY}

In this paper, we used quantitative analysis of the collected data concerning the factors influencing out-of-pocket expenses in healthcare. Namely, following the trends in research of this type of costs and based on the literature review, we predicted three different groups of factors influencing the out-of-pocket expenses. The dependent variable is Out-of-pocket expenditure per capita (current US \$) for the Republic of Serbia. Data were collected for the period from 2000 to 2018 (data were collected based on the World Bank database) (2). The first group is created from economic indicators, and this group consists of Gross Domestic Product, labor (total population), and Gross salary (average). The group of demographic indicators includes the parameters of the total population and the population older than 65 years. The group of factors related to the organization of the health system includes factors: the number of nurses (per 1000 people), the number of doctors (per 1000 people), hospital beds (per 1000 people), Out-of-pocket expenditure (\% of current health expenditure), Domestic general government health expenditure (\% of current health expenditure), Current health expenditure (\% of GDP), DALYS (Disability-Adjusted Life Years) - All causes, DALYS Disability-Adjusted Life Years) - Communicable, maternal, neonatal, and nutritional diseases. 


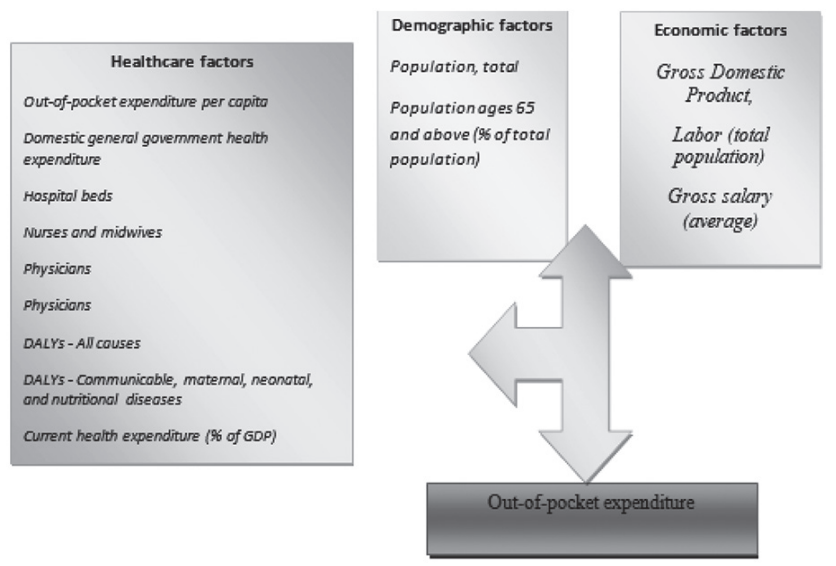

Figure 1. Theoretical framework and selected variables affecting out-of-pocket expenditure

\section{Quantitative analysis}

In this paper, we use quantitative analysis of selected independent variables and their impact on out-of-pocket expenditure selected as dependent variable. For this analysis, the programming language " $\mathrm{R}$ " is used, which enables applications of various econometric analyzes. The dataset was collected through the World Bank database as previously indicated. Although the dataset contains data for 18 years (2000-2018), after data analysis and minimum sample size, it was found that this database size could be used for analysis. In addition, we were confronted with a certain number of missing data for analysis that we resolved via the imputing formula in " $R$ ". The MICE method (Multivariate Imputation via Chained Equations) was used, which is one of the most widely used models for this purpose and can only be used for quantitative data that can be considered to be missing from a random model. The principle for use is as follows: if the value in the dataset for the variable " $\mathrm{Ho}$ spital beds" is missing, then the model will regress according to other observed variables, and the missing values will be replaced by the predicted data (i.e., by using linear regression to predict missing values) (12).

Firstly, we assessed the number of missing values and their position within the data. This was done through the "aggregated" function. The coding and results are shown below through a histogram of the missing data. It was recorded that these are variables that refer to the number of physicians, hospital beds, and nurses and after - the use of linear regression through PMM (Predictive Mean Matching). 


$\begin{array}{r}>\text { library(VIM) } \\ >\text { missing data }\end{array}$
$\quad \begin{array}{r}\text { numbers=TRUE, sortVars=TRUE, } \\ \text { labels=names (data.mis), cex.axis=.7, } \\ \text { gap=3, ylab=c("Missing data", "Pattern")) }\end{array}$
Library(MICE)
$\begin{array}{r}>\text { missing data_imputing <- mice(data.mis, m=5, maxit }=50, \text { method = 'pmm', } \\ \text { seed = 500) } \\ >\text { summary(missing data_imputing) }\end{array}$

Image 1. Coding in " $\mathrm{R}$ " for understanding missing values and imputing them through Predictive Mean Matching
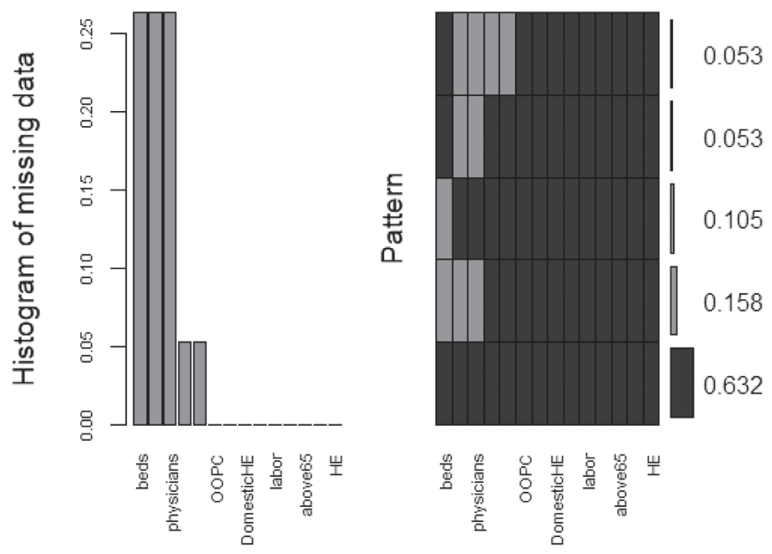

Figure 2. Histogram of missing values for imputing

Multiple regression analysis is a common quantitative method for use for analysis of multiple independent variables impact on selected dependent variable (13). In the following, we used the predicted dataset for further research and regression analysis. The formula for regression analysis is based on the following formula:

$$
\mathrm{Y}=\mathrm{a}+\mathrm{b} X_{1}+\mathrm{c} X_{2}+\mathrm{d} X_{3}+\mathrm{c} X \mathrm{k}+\mathrm{\epsilon}
$$

Where: $Y$-Dependent variable; $X 1, X 2, X k$ - independent or exploratory variables; $\boldsymbol{b}, \boldsymbol{c}$..- slopes; $\boldsymbol{\epsilon}$ - residual error.

" $R$ " code for multiple regression analysis was made as follows (according to coded names of selected variables) and following the theoretical framework:

$\operatorname{lm}($ formula $=$ OOPC $\sim$ OOPHE + HE + DomesticHE + GDP + beds + nurses + physicians + population + above $65+$ labor + Grosssalary + DALY_all + DALY_communicable) 


\section{RESULTS}

Results of regression analysis showed that 7 out of 13 factors have a very high impact on the out-of-pocket health expenditure. We have set the significance level of $p$-value at $<0.05$. Following variables have shown significant impact on the dependent variable: OOPHE (Out-of-pocket expenditure (\% of current health expenditure)) is showing p-value $=0.005 ; \mathrm{HE}$ (Current health expenditure (\% of GDP)) has a p-value of 0.01; DomesticHE (Domestic general government health expenditure (\% of current health expenditure)) has $\mathrm{p}$-value $=0.03 ; \mathrm{GDP}$ (GDP (current US\$)) has $\mathrm{p}$-value $=0.0003$; population (Population, total) $\mathrm{p}$-value $=0.01$; above 65 (Population ages 65 and above ( $\%$ of total population)) has $\mathrm{p}$-value $=0.009$, labor (Labor force, total) has p-value $=0.01$. Multiple R-Squared and Adjusted R-Squared values are showing a high level of model fit, explaining more than $80 \%$ of the observed cases. The standard error is in certain cases large, which might lead to the conclusion of the requirement for dataset revision. Analysis of coefficients shows the direct relationship in all cases except in case of total population and above 65 group (considering variables affected by a $p$-value $<0.05$ ).

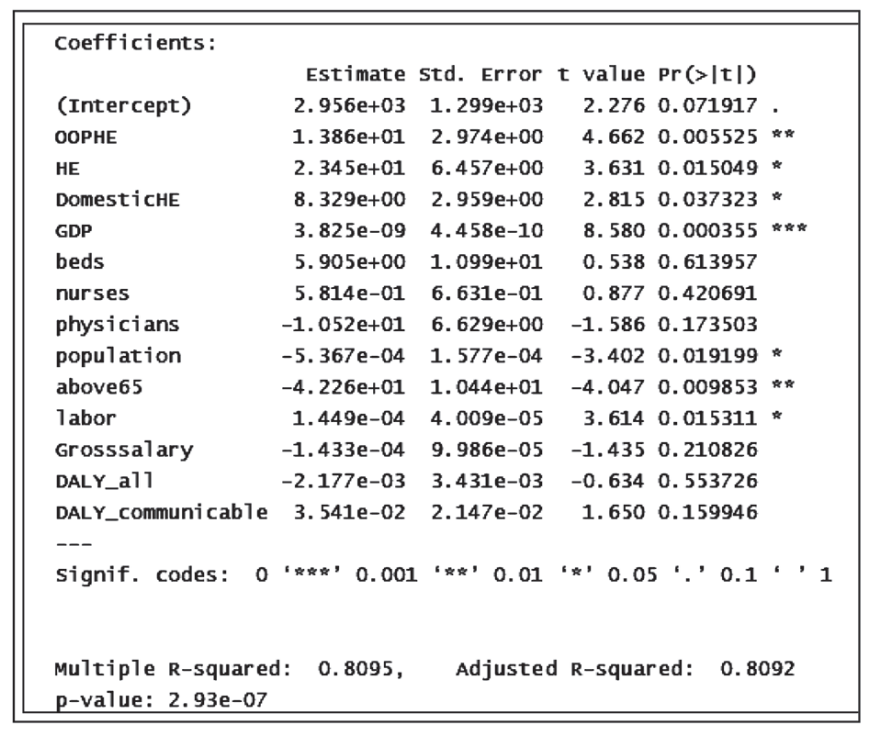

Table 1. Regression analysis in " $R$ " - results

As it might be seen in the plot of the data, dispersion of data is still on a notable level. This was not changed significantly even with the application of the logarithmic function. 


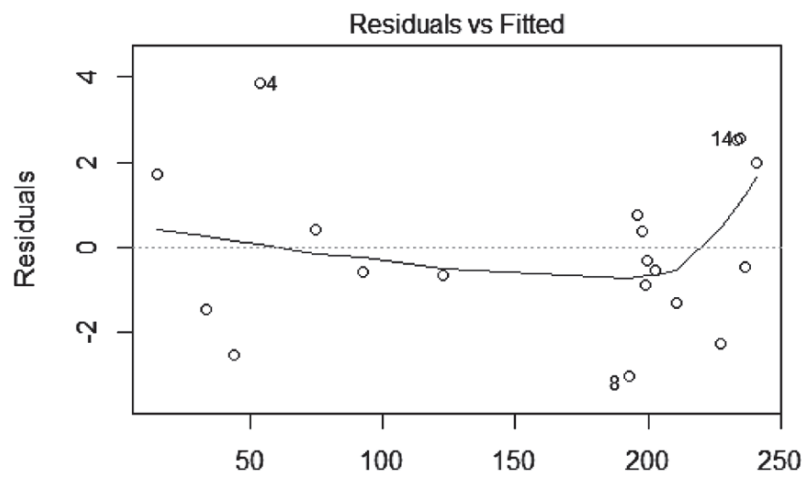

Fitted values

IOPC $\sim$ OOPHE + HE + DomesticHE + GDP + beds + nurses + physicians

Figure 3. Model fitted values/residuals

\section{CONCLUSION}

Interpretation of the results is showing that Out-of-pocket expenditure ( $\%$ of current health expenditure) has a significant impact on the observed dependent variable Out-of-pocket expenditure per capita (current US \$) for the Republic of Serbia for the period 2000-2018. This was expected as by the rise of out-of-pocket expenses, we expect to have the rise of out-of-pocket expenditure at the national level (in case there was no drastic change in financing healthcare system by the government - which was confirmed). Same could be observed for the indicator Current health expenditure (\% of GDP). On the other hand, the control variable Domestic general government health expenditure (\% of current health expenditure) shows the certain variation in government involvement in financing the healthcare system through the observed period, and there was significance between more investments from government and higher out-of-pocket expenses. It would be expected that with the rise of government share in financing healthcare system, out-of-pocket expenses would decrease. Indicator Gross Domestic Product has shown a large level of impact on the out-of-pocket expenses, but this was observed for the majority of countries on the global level as there is a trend in both growth of global GDP and global out-of-pocket expenses. This trend is explained as by becoming wealthier, people are investing more in healthcare besides the restrictive capacities of current healthcare systems.

By becoming wealthier, people are investing more in healthcare besides the restrictive capacities of current healthcare systems. From the other hand it was shown a negative relationship among the total population and population above 65 years old. Previous analysis suggested continuing further research on 


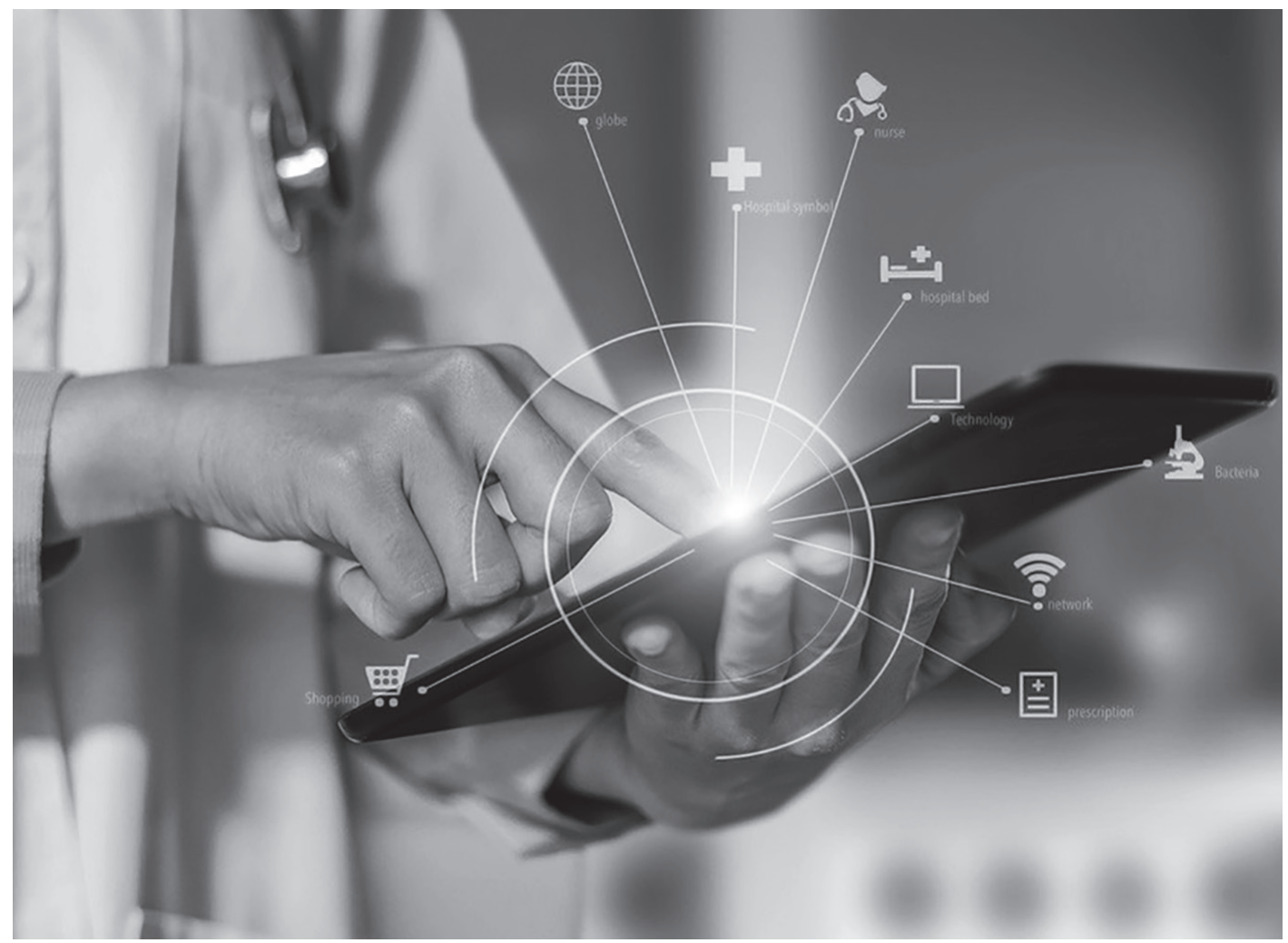

these topics that would provide a better insight into the factors influencing out-of-pocket expenses. The limitation of this research is in a relatively small dataset observing 19 years' timeframe (annual results of each observed indicator). What is also interesting is that in the Republic of Serbia, reimbursement on the basis of insurance for public medical services is not at a high level, so if it were compared to other countries, that amount as a direct cost for consumers would be even higher.

This paper points to the cross-functional significance of factors influencing out-of-pocket expenses in the areas of health, economics, and demography. Therefore, as the theory considers out-of-pocket expenses to have a very significant impact on the finances of each household, it is important to pay more attention to the factors that contribute to the amount of these costs in the future. Impact on the overall healthcare system should not be neglected and required reforms should be implemented in accordance with the accessed need. 


\section{LITERATURE}

1. Healthcare.gov. (2020) Out of pocket costs. Available at: https://www.healthcare.gov/glossary/out-of-pocket-costs/, Accessed on 01/02/2021

2. World Bank, (2020) Data indicators. Available at: https://data.worldbank.org/indicator/SH.XPD.OOPC.PC.CD, Accessed on 15/01/2021

3. Croso.gov. (2020) Stope doprinosa. Available at: http://www.croso.gov.rs/lat/Statistika/Stope_doprinosa/. Accessed on 15/01/2021.

4. Imlak, S. Shabda, S. (2016) A Study of Out-of-pocket Health Expenditures: A Case of South Asian Countries. Journal of Health Management.Vol 18, Issue 4, $2016 . \quad$ https://doi. org/10.1177/0972063416666349.

5. Okello, N., Njeru A. (2015) Factors Affecting Out-Of-Pocket Medical Expenditure Among Out-Patients in Hospitals in Nairobi County. International Journal of Scientific and Research Publications. volume 5, Issue 6, June 2015. ISSN 2250-3153. Available at: http://www.ijsrp.org/research-paper-0615/ijsrp-p42109.pdf.

6. Ebaidalla, M. Ali, M.E. (2019). Determinants and impact of household's out-of-pocket healthcare expenditure in Sudan: evidence from urban and rural population .Volume 11. Issue 2 181-198. https://doi.org/10.1080/17938120.2019.1668163

7. Mahumud, R. A. et al. (2017) Distribution and Determinants of Outof-pocket Healthcare Expenditures in Bangladesh. Journal of preventive medicine and public health = Yebang Uihakhoe chi, 50(2), 91-99. https://doi.org/10.3961/jpmph.16.089.

8. Petrera, P. M., Jiménez Sánchez, E. (2018) Determinantes del gasto de bolsillo en salud de la población pobre atendida en servicios de salud púbicos en Perú, 2010-2014. Rev Panam Salud Publica. 2018;42:e20. https://doi.org/10.26633/RPSP.2018.20.

9. Jelisavac Trosic, S. Todic, D. Stamenovic M. (2019) Svetska trgovinska organizacija - životna sredina i sistem zdravstvene zaštite. Institute for International Politics and Economy, Belgrade. ISBN 978-86-7067257-4, COBISS.SR-ID 272327436.

10. Stamenović, M. (2019) Post-transitional Status and Selected Challenges of the Serbian Health System, in: Auditor no. 85, Publisher: RSM Advisor, p. 31-47, ISSN 1450-7005, COBISS.SR-ID 275895308.

11. Rabrenović, M. et al. (2020) STEPEN OSTVARENE LIBERALIZACIJE EKONOMIJE SRBIJE U PROCESU PRISTUPANJA SVETSKOJ TRGOVINSKOJ ORGANIZACIJI. DOI: 10.5937/MegRev2003065R. Megatrend review. Vol. 17, No. 3, 2020: 65-78.

12. Cran.r. (2021) Multivariate Imputation by Chained Equations. Available at: https://cran.r- project.org/web/packages/mice/mice.pdf. Accessed on 15/01/2021

13. Stamenovic, M. (2020) QUANTITATIVE ANALYSIS OF BIOTECHNOLOGY PATENTS NEXUS TO NATIONAL ECONOMIES AND POLICIES. JOurnal Auditor. Issue 89-90. 7-17.

DOI: https://doi.org/10.5937/Rev2090007S

\section{INTERSEKTORSKA ANALIZA FAKTORA UTICAJA NA DIREKTNE TROŠKOVE IZ DŽEPA GRAĐANA ZA ZDRAVSTVENE USLUGE U SRBIJI REZIME}

Ključne reči: demografski faktori, zdravstveni faktori, troškovi iz džepa, socijalno-ekonomski faktori.

Troškovi zdravstvene zaštite iz džepa građana pokazuju nivo direktnih troškova pojedinaca koji plaćaju zdravstvene usluge koje nisu pokrivene osiguranjem. U Republici Srbiji prisutan je visok nivo troškova iz džepa uzimajući u obzir dominantan Bizmarkov model zdravstvene zaštite ali i nivo prihoda građana. Prethodna istraživanja pokazala su značajan uticaj faktora socio-ekonomskog i zdravstvenog sistema koji utiču na troškove iz džepa. Cilj istraživanja je da utvrdi značajne faktore uticaja među odabranim ekonomskim, zdravstvenim i demografskim varijablama na ukupne troškove iz džepa za zdravstvene usluge. Koristimo kvantitativne metode analize podataka za vremenski okvir podataka od 2000. do 2018. godine. Rezultati pokazuju visok uticaj 7 od 13 faktora koje smo istražili. 